\title{
THE ANTIBACTERIAL EFFECT OF ENZYMATIC HYDROLYZED VIRGIN COCONUT OIL ON Propionibacterium acne, Bacillus subtilis, Staphylococcus epidermidis AND METHICILLIN-RESISTANT Staphylococcus aureus
}

\author{
Linda Margata ${ }^{1}$, Jansen Silalahi ${ }^{1 *}$, Urip Harahap ${ }^{2}$, Dwi Suryanto ${ }^{3}$ \\ and Denny Satria ${ }^{4}$ \\ ${ }^{1}$ Department of Pharmaceutical Chemistry, Faculty of Pharmacy, \\ Universitas Sumatera Utara, Indonesia \\ ${ }^{2}$ Departement of Pharmacology, Faculty of Pharmacy, Universitas Sumatera Utara, Indonesia \\ ${ }^{3}$ Department of Biology, Faculty of Mathematics and Natural Sciences, \\ Universitas Sumatera Utara, Indonesia \\ ${ }^{4}$ Department of Pharmaceutical Biology, Faculty of Pharmacy, \\ Universitas Sumatera Utara, Indonesia \\ *E-mail : jansen@usu.ac.id
}

\begin{abstract}
Infection is one of the world's biggest health problems that cause high morbidity and mortality. It is important to search for new compounds which exert antibiotic activity especially for microorganisms which are already resistant to the known antibiotics. The aim of this work was to investigate the antibacterial effect of enzymatically hydrolyzed virgin coconut oil on some pathogenic bacteria. Virgin coconut oil was hydrolyzed enzymatically using lipase from Rhizomucormiehei. The antibacterial test was conducted by the agar diffusion method using 6 mm paper discs (Oxoid) to observe the zone of inhibition. Tested bacteria were Propionibacterium acne (ATCC 6918), Bacillus subtilis(ATCC 6633), Staphylococcus epidermidis(ATCC 12228)and methicillin-resistant Staphylococcus aureus(MRSA).Non-hydrolyzed virgin coconut oil did not show antibacterial activity on all bacteria tested, while hydrolyzed virgin coconut oil did. Antibacterial activity of hydrolyzed virgin coconut oil was shown to be concentration-dependent. As concentration increased, the zone of inhibition also became larger. Hydrolyzed virgin coconut oil $50 \%$ gave inhibition zone of $10.08 \mathrm{~mm}$ for P. acne, $10.53 \mathrm{~mm}$ for B. subtilis, $12.33 \mathrm{~mm}$ for S. epidermidisand $10.20 \mathrm{~mm}$ for MRSA. VCO did not show antibacterial properties, while HVCO exerted an antibacterial effect on all tested bacteria in this study including MRSA.
\end{abstract}

Keywords: Virgincoconut oil, Propionibacterium acne, Bacillus subtilis, Staphylococcus epidermidis, methicillinresistant Staphylococcus aureus

(C) RASĀYAN. All rights reserved

\section{INTRODUCTION}

Infection is one of the world's biggest health problems that cause high morbidity and mortality. Million species of microbes are present in the human body and they give some benefits in nutrition and immune system. These organisms describe the difference between colonization (not harmful condition) and infection (pathogenic condition). A harmless colony in one location of the body (gastrointestinal and skin) could be harmful if the same organism is present in another location (blood circulation, heart valve). ${ }^{1-}$ ${ }^{2}$ Bacteria normally found in human gut and skin such as Bacillus subtilis, Propionibacterium acneand Staphylococcus epidermidisare associated with invasive infections, such as food poisoning, skin infections, pneumonia, osteomyelitis, sepsis and infectious endocarditis. ${ }^{3-6}$

Antibiotics are synthetic chemical compounds that affect microorganisms' survival by inhibiting their growth or killing them. Currently, antibiotics are vastly available worldwide. However, according to the

Rasayan J. Chem., 12(2), 987-993(2019)

http://dx.doi.org/10.31788/RJC.2019.1225113

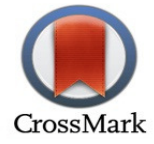


RASĀYAN J. Chem.

Vol. 12 | No. 2 |987 - 993| April - June | 2019

investigation establishedby the U.S Centers for Disease Control and Prevention (CDC\&P), between 2000 and 2008, the number of sepsis cases increased from 621.000 to 1.141 .000 cases, with mortality rate increased from 154.000 to 207.000. One of the reasons is because of the occurrence of methicillinresistant Staphylococcus aureus(MRSA), a strain that cannot be eradicated by methicillin, the most effective derivative of penicillin. In 2014, CDC\&P reported the list of 18 microbes which are resistant to antibiotic and endanger theAmericans' health. ${ }^{7-8}$

Changes in society, technology and microorganisms cause the occurrence of new diseases, reoccurrence of controlled diseases and development of antimicrobial resistance. World Health Organization (WHO) has warned that post-antibiotics era will increase the frequency of infection's occurrence and small injuries could lead to death if we fail to solve it. On the other hand, antibiotic resistance also increases the frequency of antibiotics' usage. Patients who routinely use antibiotics are known to have $50 \%$ more chance to be diagnosed with type 2 diabetes mellitus (DM). Therefore, it is important to search for new compounds which exert antibiotic activity especially for microorganisms which are already resistant to the known antibiotics. ${ }^{7-8}$

Antimicrobial properties of fatty acid and its ester have been known since 1966. Medium chain fatty acid (MCFA) and its derivative (monoglyceride) are effective against some organismssuch as bacteria, fungi, virus and protozoa. The antimicrobial action of MCFA and its derivative is caused by their abilities to damage the lipid membrane of organisms. ${ }^{9-11}$ Virgin Coconut Oil (VCO) is an example of oil composed mainly of MCFA (64\%), which consist of lauric acid (48-53\%), capric acid (7\%), caprylic acid (8\%) and caproic acid $(0.5 \%)$. In the body, each MCFA will be converted into their monoglycerides (monolaurin, monocaprin, monocaprillin and monocaproin) which possess antimicrobial activity. Monolaurin is the component that has the most important role of VCO's antimicrobial activity. ${ }^{9,12}$

Studies about VCO and its hydrolyzed product (HVCO) on some bacteria such as Pseudomonas aeruginosa, Staphylococcus aureus, Staphylococcus epidermidis, Propionibacterium acne, Salmonella typhii, Eschericia coli, Bacillus cereus and Mycobacterium tuberculosis have been reported ${ }^{13-19}$. However, study on VCO and its enzymatically hydrolyzed product on some bacteria especially bacteria reported to be resistant to antibiotics still requires to be developed. The aim of this research was to examine the antibacterial effect of VCO and its enzymatically hydrolyzed product on P. acne, B. subtilis, S. epidermidisand MRSA.

\section{Enzymatic Hydrolysis of Virgin Coconut Oil}

Thirty (30) g of VCO (PalemMustika ${ }^{\circledR}$, Indonesia), $30 \mathrm{ml}$ of distilled water, $12.5 \mathrm{ml}$ of $0.063 \mathrm{M}$ calcium chloride, $25 \mathrm{ml}$ of buffer Tris- $\mathrm{HCl} 1 \mathrm{M} \mathrm{pH} 8$ and $3 \mathrm{ml}$ of lipase from Rhizomucormiehei $(\geq 20000 \mathrm{U} / \mathrm{g})$ (Sigma Aldrich®, USA) were transferred into $250 \mathrm{ml}$ Erlenmeyer flask, respectively. The solution was incubated at $50{ }^{\circ} \mathrm{C}$ and stirredat $200 \mathrm{rpm}$ every 1 hour for 10 minutes. After 10 hours, the solutionwas transferred into the separatory funnel and then $50 \mathrm{ml}$ of $\mathrm{n}$-hexane was added to extract the non-polar fraction. The extract was allowed to stand for a while to form two separated layers. The above layer (nhexane fraction) was separated (filtrate I), while the bottom layer (water fraction) was extracted again with50 $\mathrm{ml}$ of $\mathrm{n}$-hexane. The second extract was allowed to stand for a while and then the above layer formed was separated (filtrate II). Filtrate I and II were mixed and then $250 \mathrm{~g}$ of sodium sulfate anhydrous was added and allowed to stand for 15 minutes to absorb the water residue. The mixture was filtered, then $\mathrm{n}$-hexane was evaporated using a water bath to obtain $\mathrm{HVCO} .^{20}$

\section{Antibacterial Activity Test}

Bacteria used in this study were Propionibacterium acne (ATCC 6918), Bacillus subtilis(ATCC 6633), Staphylococcus epidermidis(ATCC 12228) and methicillin-resistant Staphylococcus aureusobtained from Laboratory of Microbiology, Faculty of Pharmacy, Universitas Sumatera Utara.

Bacteria inoculums were prepared by transferring bacteria colonies using a sterile inoculating loop and suspending them in $10 \mathrm{ml}$ of nutrient broth (Oxoid). The turbidity of bacteria cultures was compared to the turbidity of McFarland No. 0.5 reference standard (bacteria concentration $1 \times 10^{8} \mathrm{cfu} / \mathrm{ml}$ ). ${ }^{21-22}$ The volume of $0.1 \mathrm{ml}$ bacteria inoculums was mixed with $15 \mathrm{ml}$ nutrient agar (Oxoid) in a petri dish, allowed to stand until the media solidified. The antibacterial test was conducted by diffusion agar method using a 
paper disc with $6 \mathrm{~mm}$ in diameter (Oxoid) to observe the zone of inhibition. Antibacterial activity test was carried out on the non-hydrolyzed VCO and hydrolyzed VCO with a concentration of $3.125 \%, 6.25 \%$, $12.5 \%, 25 \%$ and $50 \%$ in dimethyl sulfoxide (DMSO). Antibacterial activity of VCO and HVCO were compared with ampicillin with a concentration of 0.025 and $0.05 \mathrm{mg} / \mathrm{ml}$ in DMSO (for P. acne, B. subtilis and $S$. epidermidis) and $2.5 \mathrm{mg} / \mathrm{ml}$ and $5 \mathrm{mg} / \mathrm{ml}$ in DMSO (for MRSA). ${ }^{16-19,23-25}$

\section{Statistical Analysis}

All data were analyzed statistically using one-way analysis of variancefollowed by the Tukey method to find means that are significantly different between each group. The analysis was doneusing computerized SPSS package program (SPSS 17.0 software for Windows). Results are stated as mean \pm standard deviation and considered significantly different at $\mathrm{p}<0.05$.

\section{RESULTS AND DISCUSSION}

Antibacterial activities of VCO, HVCO and ampicillin on P. acne, B. subtilis, S. epidermidisand MRSA were seen by the presence of inhibition zone. Inhibition zone is the transparent area formed around the paper disc as shown in Figs.-1, 2, 3, 4 and Table-1.
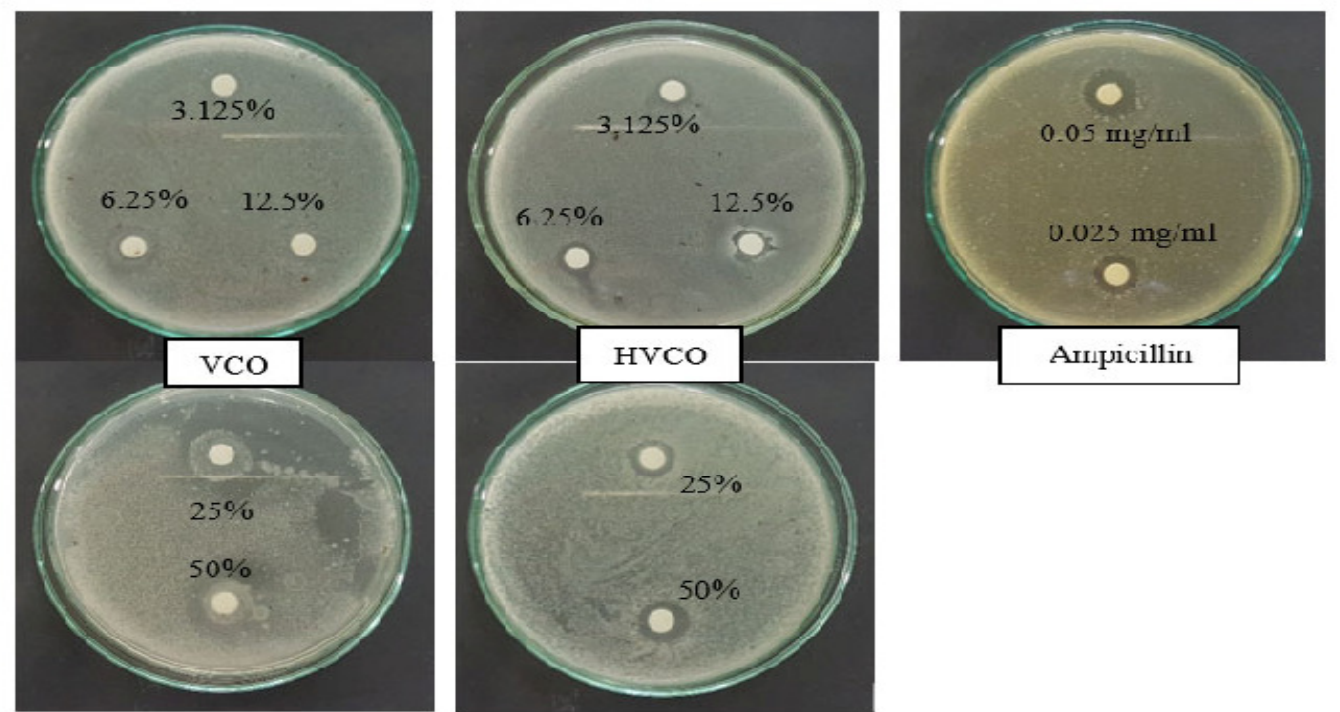

Fig.-1: Inhibition Zone of VCO, HVCO and Ampicillin in Various Concentrations on Propionibacterium acnein vitro
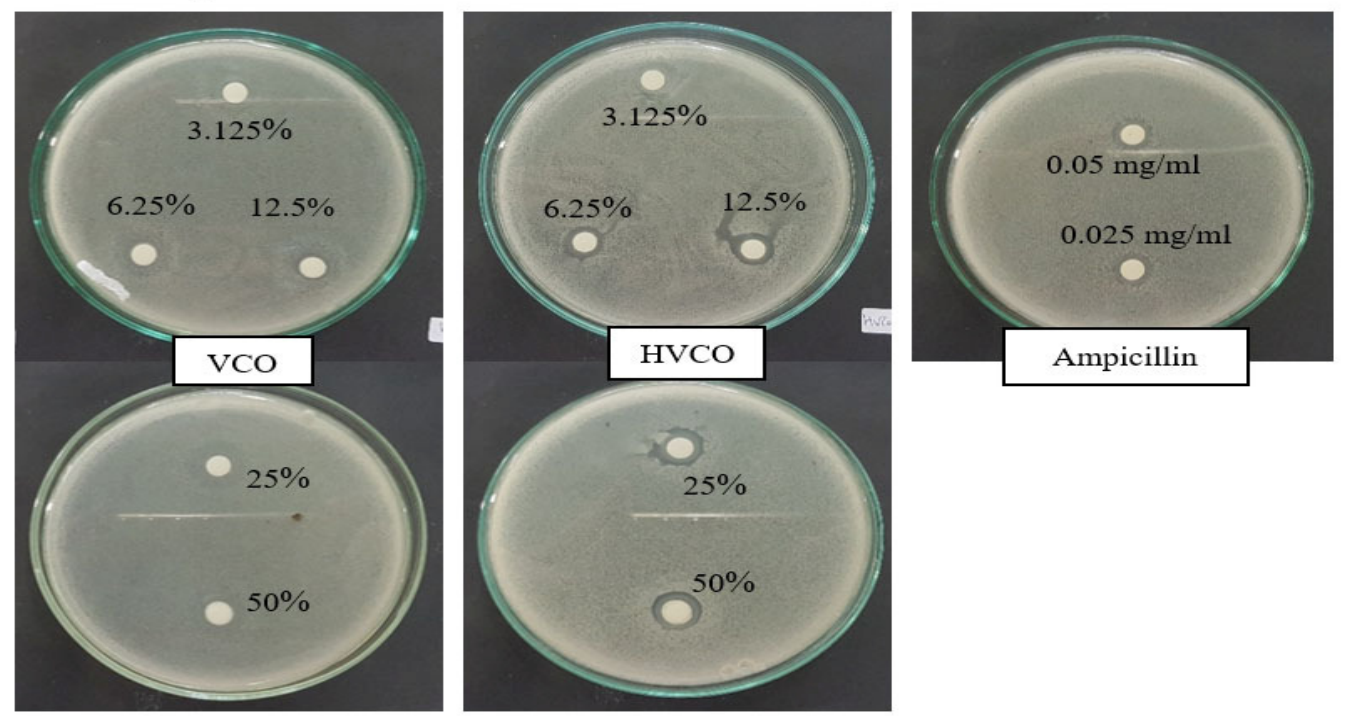

Fig.-2: Inhibition Zone of VCO, HVCO and Ampicillin in Various Concentrations on Bacillus subtilisin vitro 989 

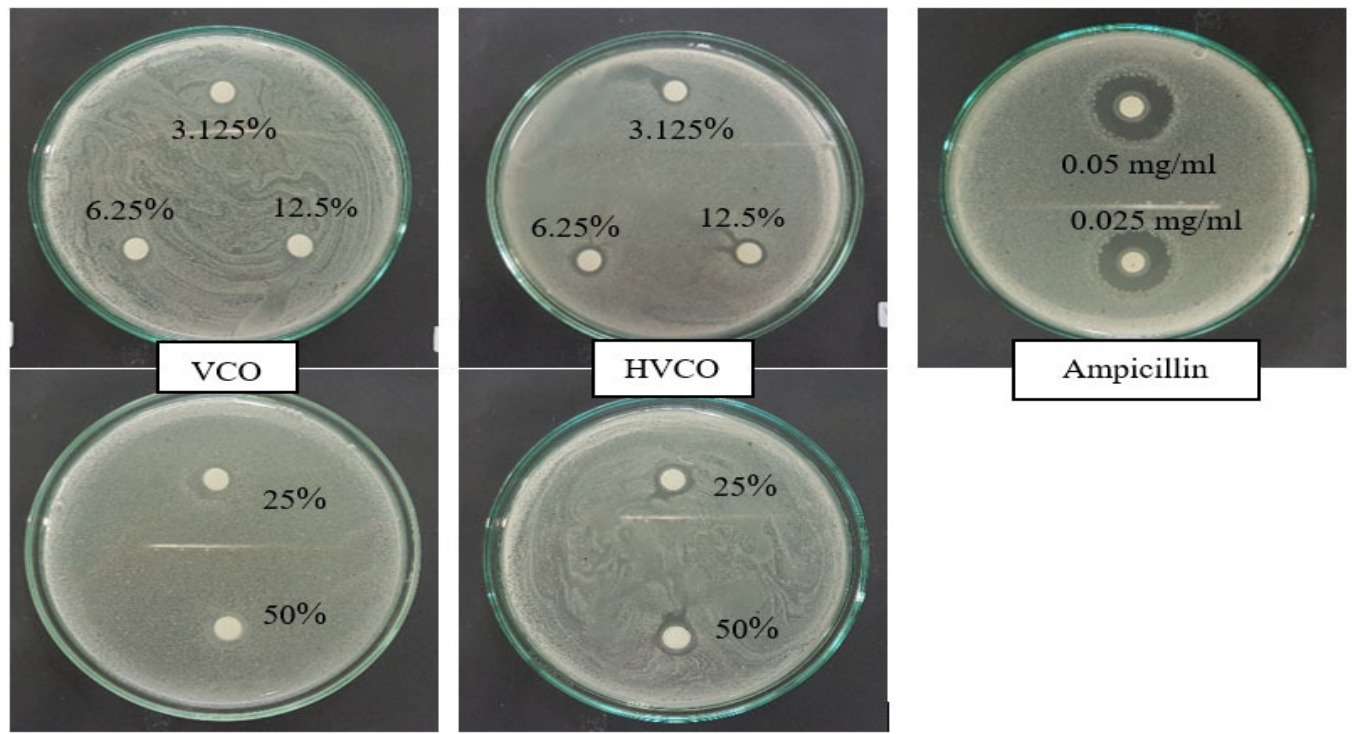

Fig.-3: Inhibition Zone of VCO, HVCO and Ampicillin in Various Concentrations on Staphylococcus epidermidis in vitro
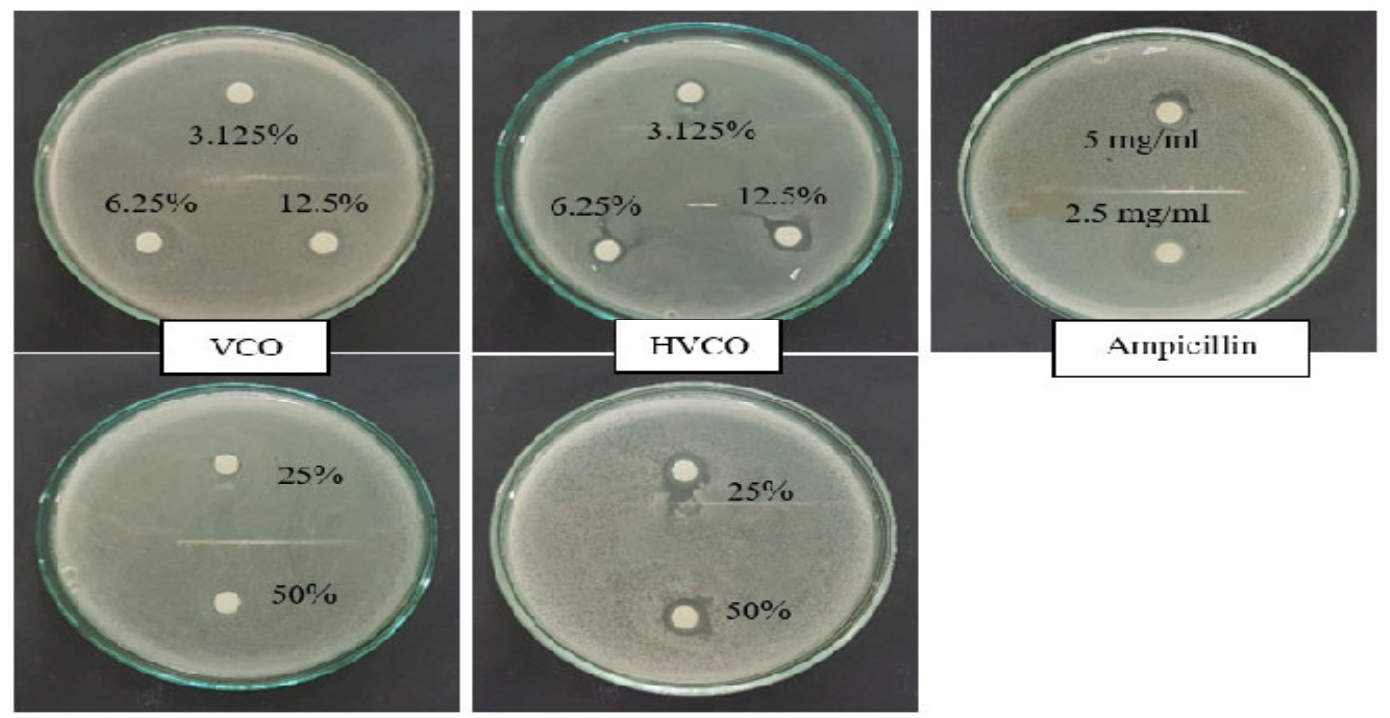

Fig.-4: Inhibition Zone of VCO, HVCO and Ampicillin in Various Concentrations on Methicillin-resistant Staphylococcus aureus in vitro

As seen in Table-1, the results of this study show that VCO did not have an antibacterial effect on all the bacteria tested, even after increasing the concentration up to $50 \%$. On the other side, HVCO exhibited an antibacterial effect on all bacteria tested and the inhibition zone increased as the concentration increased. HVCO 50\% gave the best antibacterial activity with an inhibition zone of $10.88 \mathrm{~mm}$ for P. acne, 10.53 $\mathrm{mm}$ for B. subtilis, $10.58 \mathrm{~mm}$ for S. epidermidis and $10.20 \mathrm{~mm}$ for MRSA. HVCO and ampicillin did not give significantly different inhibition zone on bacteria tested, except for $S$. epidermidis. Inhibition zone on $S$. epidermidis caused by ampicillin was significantly higher than the inhibition zone caused by HVCO.

The size of the inhibition zone caused by HVCO and ampicillin on P. acne are shown to be significantly different. Ampicillin with the concentration of $0.05 \mathrm{mg} / \mathrm{ml}$ gave the largest inhibition zone which was 12.48. HVCO $50 \%$ and $25 \%$ gave inhibition zones $(10.88 \mathrm{~mm}$ and $10.35 \mathrm{~mm}$, respectively) which are larger than the inhibition zone caused by ampicillin $0.025 \mathrm{mg} / \mathrm{ml}(10.08 \mathrm{~mm})$. These results show that HVCO might have the same antibacterial effect with ampicillin if HVCO concentration was being increased. 
RASĀYAN J. Chem.

Vol. 12 | No. 2 |987 - 993| April - June | 2019

Table-1: Antibacterial Effect of VCO, HVCO and Ampicillin in Various Concentration against Propionibacterium acne, Bacillus subtilis, Staphylococcus epidermidis, and methicillin-resistant Staphylococcus aureus

\begin{tabular}{c|c|c|c|c|c}
\hline \multirow{2}{*}{$\begin{array}{c}\text { Tested } \\
\text { Materials }\end{array}$} & \multirow{2}{*}{ Concentrations } & \multicolumn{4}{|c}{ Mean \pm SD } \\
\cline { 2 - 6 } & & P. acne & B. subtilis & S. epidermidis & MRSA \\
\hline \multirow{5}{*}{ VCO } & $3.125 \%$ & $6.00 \pm 0.00^{\mathrm{a}}$ & $6.00 \pm 0.00^{\mathrm{a}}$ & $6.00 \pm 0.00^{\mathrm{a}}$ & $6.00 \pm 0.00^{\mathrm{a}}$ \\
\cline { 2 - 6 } & $6.25 \%$ & $6.00 \pm 0.00^{\mathrm{a}}$ & $6.00 \pm 0.00^{\mathrm{a}}$ & $6.00 \pm 0.00^{\mathrm{a}}$ & $6.00 \pm 0.00^{\mathrm{a}}$ \\
\cline { 2 - 6 } & $12.5 \%$ & $6.00 \pm 0.00^{\mathrm{a}}$ & $6.00 \pm 0.00^{\mathrm{a}}$ & $6.00 \pm 0.00^{\mathrm{a}}$ & $6.00 \pm 0.00^{\mathrm{a}}$ \\
\cline { 2 - 6 } & $25 \%$ & $6.00 \pm 0.00^{\mathrm{a}}$ & $6.00 \pm 0.00^{\mathrm{a}}$ & $6.00 \pm 0.00^{\mathrm{a}}$ & $6.00 \pm 0.00^{\mathrm{a}}$ \\
\cline { 2 - 6 } & $50 \%$ & $6.00 \pm 0.00^{\mathrm{a}}$ & $6.00 \pm 0.00^{\mathrm{a}}$ & $6.00 \pm 0.00^{\mathrm{a}}$ & $6.00 \pm 0.00^{\mathrm{a}}$ \\
\hline \multirow{5}{*}{ HVCO } & $3.125 \%$ & $7.42 \pm 0.15^{\mathrm{b}}$ & $6.00 \pm 0.00^{\mathrm{a}}$ & $7.73 \pm 0.12^{\mathrm{b}}$ & $7.02 \pm 0.14^{\mathrm{b}}$ \\
\cline { 2 - 6 } & $6.25 \%$ & $8.65 \pm 0.10^{\mathrm{c}}$ & $8.25 \pm 0.24^{\mathrm{b}}$ & $8.63 \pm 0.16^{\mathrm{c}}$ & $8.85 \pm 0.19^{\mathrm{c}}$ \\
\cline { 2 - 6 } & $12.5 \%$ & $9.72 \pm 0.12^{\mathrm{d}}$ & $9.63 \pm 0.16^{\mathrm{c}}$ & $8.82 \pm 0.15^{\mathrm{c}}$ & $9.50 \pm 0.14^{\mathrm{d}}$ \\
\cline { 2 - 6 } & $25 \%$ & $10.35 \pm 0.10^{\mathrm{e}}$ & $10.17 \pm 0.12^{\mathrm{d}}$ & $9.81 \pm 0.15^{\mathrm{d}}$ & $10.03 \pm 0.16^{\mathrm{e}}$ \\
\hline & $50 \%$ & $10.88 \pm 0.15^{\mathrm{f}}$ & $10.53 \pm 0.10^{\mathrm{e}}$ & $10.58 \pm 0.12^{\mathrm{e}}$ & $10.20 \pm 0.14^{\mathrm{e}}$ \\
\hline \multirow{5}{*}{ Ampicillin } & $0.025 \mathrm{mg} / \mathrm{ml}$ & $10.08 \pm 0.23^{\mathrm{g}}$ & $7.45 \pm 0.19^{\mathrm{f}}$ & $12.33 \pm 0.19^{\mathrm{f}}$ & - \\
\cline { 2 - 6 } & $0.05 \mathrm{mg} / \mathrm{ml}$ & $12.48 \pm 0.23^{\mathrm{h}}$ & $8.18 \pm 0.15^{\mathrm{b}}$ & $18.57 \pm 0.14^{\mathrm{g}}$ & - \\
\cline { 2 - 6 } & $2.5 \mathrm{mg} / \mathrm{ml}$ & - & - & - & $6.00 \pm 0.00^{\mathrm{a}}$ \\
\cline { 2 - 6 } & $5 \mathrm{mg} / \mathrm{ml}$ & - & - & - & $6.00 \pm 0.00^{\mathrm{a}}$ \\
\hline
\end{tabular}

Means \pm SD with different superscript letters in every column differs significantly $(\mathrm{p}<0.05)$. Inhibition zone $=6 \mathrm{~mm}$ shows no antibacterial activity present.

This work also reveals that against B. subtilis, HVCO $6.25 \%$ gave inhibition zone that was not significantly different with that caused by ampicillin $0.05 \mathrm{mg} / \mathrm{ml}$, which were $8.25 \mathrm{~mm}$ for HVCO $6.25 \%$ and $8.18 \mathrm{~mm}$ for ampicillin $0.05 \mathrm{mg} / \mathrm{ml}$. However, HVCO with a concentration of $12.5 \%$ and $50 \%$ showed a larger inhibition zone $(9.63 \mathrm{~mm}$ and $10.17 \mathrm{~mm}$, respectively) than ampicillin $0.05 \mathrm{mg} / \mathrm{ml}$. This shows that HVCO exhibited better antibacterial effect rather than ampicillin.

Zone of inhibition caused by ampicillin and HVCO on S. epidermidiswere significantly different. Ampicillin both in the concentration of $0.025 \mathrm{mg} / \mathrm{ml}$ and $0.05 \mathrm{mg} / \mathrm{ml}$ gave larger inhibition zones(12.33 $\mathrm{mm}$ and $18.57 \mathrm{~mm}$,respectively) compared to all concentration of HVCO tested. This shows that the antibacterial activity of ampicillin was better than that of $\mathrm{HVCO}$ in case of against $S$. epidermidis.

This study shows that all concentrations of HVCO tested on MRSA exhibited antibacterial effect. The higher the concentration, inhibition zone resulted was larger. On the other hand, ampicillin did not give any inhibition zone at all. This shows that HVCO was better than ampicillin against MRSA because of the ampicillin resistance in MRSA. Antibacterial mechanism of ampicillin (a drug from penicillin group) is by damaging peptidoglycan layer that makes up the cell wall of positive and negative Gram bacteria. Microorganisms which are resistant to penicillin are able to generate $\beta$-lactamasewhich is an enzyme that breaks down the $\beta$-lactam ring in penicillin molecule, hence the drug is unable to inhibit the synthesis of bacteria's cell wall ${ }^{7-8,26}$.

In this study, HVCO gave antibacterial effect on all bacteria tested although the lowest concentration which was $3.125 \%$, did not show antibacterial activity on B. subtilis. VCO hydrolyzed enzymatically with lipase from $R$. mieheiwhich is specific on sn-1 and sn-3 position of triglyceride moleculewill produce two molecules of free fatty acids and 2-monoglyceride especially lauric acid and 2-monolaurin, which are the main components of VCO. Lauric acid and monolaurin exert the highest antibacterial activity compared to other free fatty acid and monoglycerides such as butiric acid, caproic acid, caprylicacid, capric acid, myristic acid, palmitic acid, myristoleic acid, palmitoleic acid, oleic acid, linoleic acid, linolenic acid, monocaprilin, monomyristin, monopalmitin and monostearin. ${ }^{27-29}$

It is shown that VCO did not exertantibacterial effect on all bacteria tested (inhibition zone $=6 \mathrm{~mm}$ ). This was because of the low content of free fatty acids and monolaurin presented in the VCO used in this 
study. Although VCO is composed mainly of MCFA, it will not exhibit antibacterial effect because those fatty acids are bound in a triglyceride molecule. Hydrolysis products of medium chain triglyceride, which are MCFA and monoglyceride, are the important compounds in killing and inactivating pathogenic microorganism ${ }^{30}$. This result corresponds to other studies reported. VCO before hydrolyzed did not have antimicrobial properties against Salmonella typhii, Salmonella typhimuriumand Candida albicans. ${ }^{14,17}$

On the basis of inhibition zone's diameter, antibacterial effect evaluation is classified into three categories which arehigh activity (larger than $11 \mathrm{~mm}$ ), moderate activity (between 6-11 mm)and non-active $(6$ $\mathrm{mm}) .{ }^{15}$ According to the classification above, HVCO $50 \%$ could be classified as an antibacterial compound which has moderate activity and might increase to high activity if the concentration is increased to more than $50 \%$.

\section{CONCLUSION}

VCO did not exert antibacterial activity on P. acne, B. subtilis, S. aureus, and MRSA, while HVCO had antibacterial activity on all the bacteria tested. HVCO gave the highest antibacterial activity against $P$. acne. Of all bacteria tested, HVCO gave the lowest activity against MRSA. However, HVCO gave a better effect compared to ampicillin.

\section{ACKNOWLEDGMENT}

Authors are grateful for the financial support from the Ministry of Research, Technology and Higher Education of the Republic of Indonesia through "Program Magister Menuju Doktor untuk Sarjana Unggul (PMDSU)" Research Grant 2018.

\section{REFERENCES}

1. M.L. Cohen, Nature, 406, 762 (2000), DOI:10.1038/35021206

2. H.V. Fineberg, M.E. Wilson, IRGC Rep (2010).

3. Y.L. Jeon, J.J Yang, M.J. Kim, G. Lim, S.Y. Cho, T.S Park, et al., J. Med.Microbiol.,61, 1766 (2012), DOI:10.1099/jmm.0.042275-0

4. D.J. Gonzales, N.M. Haste, A. Hollands, T.C. Fleming, M. Hamby, K. Pogliano, et al., Microbiol.,157, 2485 (2011), DOI:10.1099/mic.0.048736-0

5. Y. Achermann, E.J.C. Goldstein, T. Coenye, M.E. Shirtliff, Clin.Microbiol. Rev.,27(3), 419 (2014), DOI:10.1128/CMR.00092-13

6. D. Chessa, G. Ganau, V. Mazzarello, J.Infect.Dev.Ctries.,9(6), 547 (2015), DOI:10.3855/jidc.6923

7. A.L. Fymat, Biomed. J.Sci.\& Tech. Res.,1(1), 1 (2017), DOI:10.26717/BJSTR.2017.01.000117

8. S. Zaman, M. Hussain, R. Nye, V. Mehta, M. Taib, N. Hossain, Cureus,9(6), e1403 (2017), DOI: $10.7759 /$ cureus. 1403

9. M. Enig, In AVOC Lauric Oils Symposium, Ho Chi Min, Vietnam, 25 (1996).

10. Y.B.C. Man, M.A. Manaf, 2006, Medium-Chain Triacylglycerols, in F. Shahidi (ed.), Nutraceutical and Specialty Lipids and their Co-Products, Taylor \& Francis Group LLC, USA, pp. 27-56.

11. W. Darmoyuwono, Gaya Hidup Sehatdengan Virgin Coconut Oil [Healthy Lifestyle with Virgin Coconut Oil], PT IndeksKelompokGramedia, Jakarta, p.1-20 (2006). Indonesian.

12. B. Fife, The Coconut Oil Miracle, Penguin Group (USA), Inc, New York, p.35-37 (2004).

13. G.V. Dalmacion, A.R. Ortega, I.G. Pena, C.F. Ang, Funct. Foods Health Dis.,2(8), 290 (2012), DOI:10.31989/ffhd.v2i8.82

14. S.S. Dewi, T. Aryadi, in Prosiding Seminar NasionalUnimus, Indonesia, pp. 39-41 (2010). Indonesian.

15. J. Silalahi, Y.M. Permata, E.D.L Putra, Asian J.Pharm.Clin. Res.,7(2), 90 (2014).

16. F.S. Loung, J. Silalahi, D. Suryanto. Int. J. PharmTech Res., 6(2), 628 (2014).

17. E. Elysa, U. Harahap, J. Silalahi, Int. J. PharmTech Res.,6(2), 589 (2014).

18. N.T.M. Sihombing, J. Silalahi, D. Suryanto. Int.J.ChemTech Res.,6(5), 2774 (2014).

19. J. Silalahi, R, Manurung, E. Sitompul, Int.J.PharmTech Res., 7(2), 233 (2015).

20. L. Margata, J. Silalahi, U. Harahap, D. Satria. Asian J.Pharm.Clin. Res.,11(1), 185 (2018), DOI:10.22159/ajpcr.2018.v11i10.27476

21. Ditjen POM, Farmakope Indonesia [Indonesia Pharmacopoeia], $4^{\text {th }}$ edition, Departemen Kesehatan Republik Indonesia, Jakarta,p.891 (1995). Indonesian. 
RASĀYAN J. Chem.

Vol. 12 | No. 2 |987 - 993| April - June | 2019

22. I.D. Riris, M. Simorangkir, A. Silalahi, Rasayan J. Chem., 11(3), 1229 (2018), DOI:10.31788/RJC.2018.1133090

23. G.K.R. Cyrille, S. Yaya, D. Adjehi, K.A.B. Benjamin, D.J.E. Marcellin, Rasayan J. Chem., 8(4), 396 (2015).

24. K. Anbarasu, N. Geetha, Rasayan J. Chem., 8(3), 298 (2015).

25. M. Salihovic, M. Pazalja, I. Mahmutovic-Dizdarevic, A. Jerkovic-Mujkic, J. Suljagic, S. SpirtovicHalilovic, A. Sapcanin, Rasayan J. Chem., 11(3), 1074 (2018), DOI:10.31788/RJC.2018.1133077

26. S.T. Pratiwi, Mikrobiologi Farmasi [Pharmaceutical Microbiology], Erlangga, Jakarta, p.154-160 (2008). Indonesian.

27. P. Villeneuve, F.A. Foglia, Int. News Fats, Oils Relat.Mater.,8(6), 640 (1997).

28. B.W. Petschow, R.P. Batema, L.L. Ford, Antimicrobial Agents and Chemotherapy, 40(2), 302 (1996).

29. C.Q. Sun, C.J. O'Connor, A.M. Roberton, FEMS Immunology and Medical Microbiology,36, 9 (2003), DOI: 10.1016/S0928-8244(03)00008-7

30. B. Fife, Agro Food Industry Hi Tech, 24(3), 5 (2013).

[RJC-5113/2018] 